УДК 671.12:614.8.86

ЗЛАТКЕВИЧ С.В.

Східноєвропейський національний університет ім. Лесі Украйнки

ПЕРЕДРІЙ О.I.

Луиьький національний технічний університет

\title{
РЕГУЛЮВАННЯ ВИКОРИСТАННЯ НІКЕЛЮ, КАДМІЮ ТА СВИНЦЮ В ЮВЕЛІРНИХ ВИРОБАХ
}

ЗЛАТКЕВИЧ С.В.

Восточноевропейский начиональный университет им. Леси Украинки

ПЕРЕДРИЙ О.И.

Луикий национальный технический университет

\section{РЕГУЛИРОВАНИЕ ИСПОЛЬЗОВАНИЯ НИКЕЛЯ, КАДМИЯ И СВИНЦА В ЮВЕЛИРНЫХ ИЗДЕЛИЯХ}

\author{
S.ZLATKEVICH \\ Lesya Ukrainka Eastern European National University
}

O.PEREDRIY

Lutsk national technical university

\section{REGULATIONS OF THE USE OF NICKEL, CADMIUM AND LEAD IN JEWELLERY}

\section{https://doi.org/10.36910/6775-2310-5283-2019-12-12}

Мета. Метою даної статті є аналіз впливу нікелю, кадмію та свинцю на організм людини, а також вивчення вже існуючого досвіду впровадження норм їх використання в ювелірних виробах задля розробки практичних рекомендачій щодо регламентів, які обмежують використання нікелю, кадмію та свинцю в ювелірних сплавах.

Методика. Використано методи теоретичного пошуку, системного підходу та логічного узагальнення.

Результати. Аналіз даних свідчить, щзо на українському ринку 20 \% ювелірних сплавів не стандартизовані, $i$ питання їхньої якості викликають сумніви. Зокрема, не регламентовано використання потенційно шкідливих елементів. У статті проаналізовано дані щзодо впливу нікелю, кадмію та свинцю на організм людини. Особливу увагу приділено впливу шкідливих елементів на дитячий організм, оскільки дитячі ювелірні вироби найчастіше виготовляються саме зі сплавів, що містять кадмій та нікель. Основною складністю вивчення впливу низьких доз кадмію і свинцюю на здоров'я людей $є$ те, щзо результати їх проникнення та накопичення в організмі в дитинстві можуть проявлятися протягом усього життя. Визначено основні норми регламентів різних держав, які регулюють використання ици металів у ювелірних виробах. Проведено їх порівняння та аналіз, зокрема, визначено, що норми щодо вмісту кадмію та нікелю в регламенті 
Євросоюзу REACH, американських стандартах ASTM F2999 та F2923, канадському SOR/2018-82 та китайському GB 28480 практично ідентичні. Проте стосовно норм щодо вмісту свинцю значно різняться: європейські та американські норми більш суворі, майже в 10 разів. Доведено необхідність розробки національного регламенту, який сприяв би регулюванню використання нікелю, кадмію та свинцю у ювелірних виробах.

Наукова новизна. Проблема регулювання вмісту икідливих речовин, зокрема таких металів як нікель, кадмій та свинець, у ювелірних виробах досі не отримала належної уваги в багатьох державах. У даній статті розглянуто основні причини впровадження відповідних регламентів та проаналізовано їх наявність і ефективність у світі.

Практична значимість. Розроблені рекомендації повинні стати поштовхом для регулювання вмісту нікелю, кадмію та свинџю в ювелірних сплавах у світі та зокрема в Україні.

Ключові слова: нікель, кадмій, свинещь, контактна алергія, ювелірні вироби, регламент.

Постановка проблеми у загальному вигляді і її зв'язок з важливими науковими та практичними завданнями. На українському ринку $20 \%$ ювелірних сплавів не стандартизовані, і питання їхньої якості викликають сумніви. Зокрема, особливої уваги потребує питання використання нікелю, кадмію та свинцю в ювелірних виробах, оскільки, ці метали $є$ поширеною причиною різноманітних розладів серед загальної популяції. Дослідження показали, що ці метали можуть впливати на організм навіть у низьких концентраціях, тому їх використання в ювелірних виробах $\epsilon$ ризиком для здоров'я людини, особливо для дітей та людей, схильних до алергічних реакцій.

Аналіз останніх досліджень, у яких започатковано вирішення проблеми. Сьогодні нам надана велика база детальних досліджень впливу нікелю на здоров'я. Чимало науковців розглядають проблему контактного дерматиту, а також алергії на нікель. Зокрема Фернанда Торрес і Антонелла Тості аналізують статистику алергії на нікель у світі, а також причини цієї алергії, профілактичні та терапевтичні стратегії, які допомагають уникнути або впоратися 3 алергічним контактним дерматитом. Також добре вивчені токсичні ефекти кадмію і свинцю на організм людини. Багато досліджень за ці роки довели, що кадмій може сприяти рак нирок і простати. Обмежена кількість епідеміологічних досліджень розглядає зв'язки між кадмієм і розвитком інших гормонозалежних онкологічних захворювань, таких як рак молочної залози і ендометрій. Проте досі існують суперечки щодо ризиків використання кадмію та свинцю в ювелірних виробах. Більшість вчених сходяться на думці, що переважно діти до 6 років знаходяться в небезпеці, оскільки, існує більша ймовірність, що вони приймуть кадмій чи свинець перорально. Основною складністю вивчення впливу низьких доз кадмію і 
свинцю на здоров'я людей є те, що результати їх проникнення та накопичення в організмі в дитинстві можуть проявлятися протягом усього життя, тому дослідження може тривати роками. Тим не менш, М. Натаніель Мід у своїх працях доводить, що існує реальний ризик використання кадмію в дитячих прикрасах. Інше дослідження, проведене Брюсом П. Ланфхеаром, Річардом Хорнунгом, Джейн Хоурі та іншими вченими 3 усього світу, впевнено доводить нейробіологічні ефекти низького рівня експозиції свинцю серед дітей.

Однак, існує набагато менше публікацій про регулювання використання нікелю, кадмію та свинцю в ювелірних виробах. Проблема нерегульованого використання різних металів у ювелірних сплавах залишається актуальною в багатьох країнах, в яких безпека ювелірних виробів не отримує належної уваги.

Цілі статті. Метою даної статті $є$ аналіз впливу нікелю, кадмію та свинцю на організм людини, а також вивчення вже існуючого досвіду впровадження норм їх використання в ювелірних виробах задля розробки комплексної стратегії та практичних рекомендацій щодо урядових регламентів, які обмежують використання нікелю, кадмію та свинцю в ювелірних сплавах.

Об’сктом дослідження є ювелірні вироби.

Методи дослідження. Під час дослідження використано методи теоретичного пошуку, системного підходу та логічного узагальнення.

Виклад основного матеріалу. Насамперед, коротко розглянемо вплив нікелю, кадмію та свинцю на організм людини та ризики, пов'язані 3 використанням даних металів у ювелірних сплавах.

Нікель займає перше місце за частотою позитивних патч тест реакцій. У звітах Північноамериканської групи контактного дерматиту (North American Contact Dermatitis Group) йдеться про те, що 16,2 \% популяції США має позитивну реакцію на нікель, крім того показник підвищився 3 періоду досліджень 1994-1996 років, коли становив 14,3 \%. В Центральній Європі 12,9 \% популяції мають позитивну реакцію на нікель. За даними іншого дослідження, проведеного Свропейською системою нагляду за контактною алергією (European Surveillance System of Contact Allergies), $20 \% 39871$ пацієнтів були сенсибілізовані до нікелю, з найбільшою частотою в Італії $(32,2$ \%) і найнижчою в Данії (9,7 \%). До того ж, нікель став найпоширенішим алергеном серед підлітків, оскільки, 31 \% 3 них мали позитивну патч тест реакцію на цей метал. 
Нікель може спричиняти алергічний контактний дерматит як у дітей, так і у дорослих з поширеністю в усьому світі приблизно 8,6 \%. Поширеність серед молодих осіб жіночої статі $є$ ще вищою та становить приблизно $17 \%$, а серед пацієнтів, схильних до алергічних дерматитів, поширеність алергії на нікель перевищує навіть цей показник [2].

Більшість випадків не пов'язані з професійною діяльністю, при цьому алергія на нікель вражає жінок у 10 разів частіше, ніж чоловіків, і зазвичай спричинена контактом 3 ювелірними виробами. Найпоширенішою причиною сенсибілізації є сережки, виготовлені зі сплаву, що містить нікель.

Алергічний контактний дерматит виникає, коли металеві вироби, що містять нікель, кородують під впливом людського поту, слини або інших рідин, випускаючи вільні йони, що поводять себе як гаптени та спричинюють сенсибілізацію [2].

Єдиним шляхом запобігання повторним алергічним реакціям $є$ уникнення контакту з металевими предметами, що містять нікель. Епідеміологія алергії на нікель в Свропі нещодавно змінилася, зокрема, у Данії серед жінок, що носять сережки, внаслідок впровадження регламенту щодо використання нікелю в споживних товарах. На противагу, у Сполучених штатах поширеність алергічних реакцій на нікель все ще зростає, що може бути пояснено відсутністю регулювання використання даного металу [1].

Використання кадмію та свинцю в ювелірних виробах може спричиняти системний вплив на людський організм, якщо йони відповідних металів проникнуть в організм. Свинець $є$ токсичним металом, що не розкладається в навколишньому середовищі та здатен накопичуватися в людському організмі. Особливо високі концентрації свинцю були знайдені у дешевих дитячих ювелірних виробах. Експозиція свинцю може призвести до низки проблем зі здоров'ям, зокрема, поведінкових порушень, нездатності до навчання, слабкості суглобів і м'язів, анемії, органної недостатності.

Діти до 6 років потрапляють у групу з найбільшими ризиками тому, що їхній організм перебуває на активній стадії росту. Ювелірні вироби, що містять свинець, становлять особливу загрозу для даної вікової групи, оскільки, діти схильні поміщати свої прикраси в рот, результатом чого може стати абсорбція небезпечних кількостей свинцю [5].

Обширна база даних доводить прямий зв'язок між низьким рівнем експозиції свинцю під час раннього розвитку та дефіцитом нейро-когнітивних показників, які були виявлені пізніше в дитячому та підлітковому віці. Дослідження продемонстрували наявність сукупності нейротоксичних та 
інших несприятливих наслідків дії свинцю $(\mathrm{BPb})$ в крові за концентрацій від 10 мкг/дл [6]. Більше того, у 2005 році було опубліковано результати міжнародних досліджень, що довели зв'язок між інтелектуальним дефіцитом і рівнем концентрацій свинцю у крові у дітей, що мали максимальний рівень свинцю у крові < 7,5 мкг/дл [7].

Кадмій подібний до свинцю тим, що його використання у ювелірних виробах для дітей також становить особливу загрозу. Дія кадмію на нирки, кістки та легені $\epsilon$ повністю доведеною, менш переконливі докази нейротоксичних, тератогенних і ендокринних порушень внаслідок впливу кадмію. Навіть відносно низька хронічна експозиція може призвести до незворотного ураження ниркових канальців, потенційно прогресуючи до пошкодження клубочків і ниркової недостатності. Разом $з$ цими ефектами часто спостерігається втрата кісткової тканини. Легеневі ефекти, особливо рак легенів, в значній мірі спостерігаються в популяціях, що підлягають професійному впливу [3].

Найбільший ризик кадмій та свинець становлять, якщо діти вживають його перорально, наприклад, намагаючись проковтнути ювелірний виріб. Існує також ризик, що кадмій чи свинець відокремиться від ювелірного виробу і залишиться на руках і в результаті потрапить в організм разом 3 їжею. Контакт зі шкірою у даному випадку не становить основного ризику, оскільки, шкіра не абсорбує дані метали [4].

У зв'язку з переліченими ризиками обмеження використання нікелю, кадмію та свинцю є необхідним задля безпеки споживачів в усьому світі. Низка провідних країн світу вже впровадила регламентації використання цих металів. Першим кроком до забезпечення контролю використання нікелю в Європейському союзі стала Директива щодо нікелю, яка регулювала використання даного металу в ювелірних виробах, а також інших товарах, які контактують зі шкірою. Директива про нікель встановлює обмеження на кількість нікелю, яка може вивільнятися 3 ювелірних виробів та інших продуктів, призначених для прямого та тривалого контакту зі шкірою. Ці обмеження, відомі як межі міграції, такі:

- $\quad 0,2$ мкг $/ \mathrm{cm}^{2} /$ тиждень для об’єктів, що вставляють в проколоті вуха та інші проколоті частини тіла людини (пірсинг);

- $\quad 0,5$ мкг/ $\mathrm{cm}^{2} /$ тиждень для інших об'єктів, призначених для прямого та тривалого контакту зі шкірою.

Починаючи з 1 червня 2009 року, ця директива включена до Регламенту 
REACH, зокрема, пункт 27 Додатку XVII до цього регламенту. Сьогодні Регламент ЄС № 1907/2006 щодо реєстрації, оцінки, надання дозволів і заборон використання хімічних субстанцій (REACH) регулює використання нікелю, свинцю та кадмію. REACH стосується виробництва та використання хімічних речовин, а також їх потенційного впливу як на здоров'я людини, так $\mathrm{i}$ на навколишнє середовище [8]. Важливими положеннями REACH, що регулюють використання хімічних речовин у ювелірних виробах, $\epsilon$ :

- обмежені хімічні речовини, що зазначені у Додатку XVII до $\mathrm{REACH}$, які включають: кадмій, хром (VI), свинець, нікель (міграція), поліциклічні ароматичні вуглеводні (РАН);

- речовини, що становлять високу загрозу (SVHC), в списку кандидатів 3 метою:

- стаття 7 (2) REACH «Зазначення про речовини в виробах»;

- стаття 33 REACH «Зобов'язання повідомляти інформацію про речовини в виробах».

У 2011 році в Регламент (СC) №1907/2006 (REACH) внесено зміни щодо вмісту кадмію: його заборонено використовувати для виготовлення нових ювелірних виробів, вміст елементу у наявних ювелірних виробах не повинен перевищувати 100 мг/кг.

23 квітня 2015 року Європейська комісія внесла зміни до Додатка XVII Регламенту (СC) №1907/2006 (REACH). Ці зміни внесено в Регламент REACH з метою мінімізації ризиків багаторазового впливу свинцю і його сполук на дітей, особливо у віці до 36 місяців. Введена заборона на розміщення на ринку виробів, в яких масова частка свинцю перевищує $0,05 \%$, якщо діти можуть мати доступ до даних виробів при їх використанні згідно з призначенням.

Ряд країн, такі як Сербія, Швейцарія та Туреччина, почали впроваджувати REACH-нормативні акти або перебувають у процесі прийняття такої нормативно-правової бази для переходу до більш глобалізованої системи реєстрації хімічних речовин у рамках глобальної системи Гармонізована система класифікації та маркування хімічних речовин (GHS). Деякі інші країни, що не входять до $\mathrm{CC}$, розробили свої власні стандарти та правила для ювелірних сплавів.

Державні органи Канади регулюють як вміст свинцю, так і міграцію свинцю в ювелірних виробах переважно для дітей віком до 15 років, уважно стежать за рівнем вмісту кадмію в ювелірних виробах для дітей, зокрема, в 2010 році була висловлена вимога, щоб промисловість припинила навмисне використання кадмію й у 2011 році - опублікований регламент для цих 
продуктів. Загальною основою для безпеки продукції є Закон «Про безпеку споживчих товарів (CCPSA)». Конкретні вимоги регулюються:

- «Положення про дитячі прикраси» (SOR / 2018-82);

- «Споживчі товари, які містять свинець» (SOR / 2018-83).

Зокрема, даний документ нормує використання металів у таких кількостях:

- $\quad$ кадмій - не більше 130 мг/кг;

- свинець - не більше 90 мг/кг [9].

У США виробництво ювелірних виробів, які призначені для дітей віком до 12 років, регулюються Законом «Про покращення безпеки споживчих товарів (CPSIA)». По всій країні цілий ряд юрисдикцій регулює якість і безпеку ювелірних виробів для дорослих та/або дітей 3 унікальними специфікаціями. Діє два американські стандарти для ювелірних виробів. ASTM F2923 для ювелірних виробів для дітей та ASTM F2999 для ювелірних виробів для дорослих.

Таблиця 1

Норми стандартів ASTM F2923 / ASTM F2999

\begin{tabular}{|c|c|c|c|}
\hline \multirow[b]{2}{*}{ Вид елементу } & \multicolumn{3}{|c|}{ Тип матеріалу } \\
\hline & $\begin{array}{c}\text { покриття } \\
\text { поверхні виробу }\end{array}$ & $\begin{array}{c}\text { компонент } \\
\text { ювелірного сплаву }\end{array}$ & $\begin{array}{c}\text { компонент полімерного } \\
\text { матеріалу }\end{array}$ \\
\hline Загальний свинець & $\leq 90 \mathrm{ppm}$ & $\leq 100 \mathrm{ppm} / 1.5 \%$ & $\leq 100 \mathrm{ppm} / 200$ \\
\hline Загальний кадмій & & \multicolumn{2}{|c|}{$\leq 300 \mathrm{ppm} / 1.5 \%$} \\
\hline $\begin{array}{l}\text { Екстрагований } \\
\text { кадмій }\end{array}$ & - & $\begin{array}{c}\leq 200 \text { мг (для малих } \\
\text { частин виробу) } \\
\leq 18 \text { мг (для немалих } \\
\text { частин) }\end{array}$ & $\begin{array}{c}75 \text { ррm (для малих } \\
\text { частин виробу) } \\
\leq 18 \text { мг (для немалих } \\
\text { частин) }\end{array}$ \\
\hline Міграція нікелю & - & $\begin{array}{l}\leq 0.2 \text { мкг } / \mathrm{cm}^{2} / \text { тиждень } \\
\leq 0,5 \text { мкг } / \mathrm{cm}^{2} / \text { тиждень }\end{array}$ & $\begin{array}{c}\text { Не регламентується, } \\
\text { але виробник } \\
\text { зобов’язаний } \\
\text { проставляти на } \\
\text { маркуванні } \\
\text { інформацію про } \\
\text { наявність нікелю }\end{array}$ \\
\hline
\end{tabular}


У Китаї впроваджено два обов'язкових стандарти щодо ювелірних виробів:

- $\quad$ GB 28480 «Положення про прикраси для обмеження шкідливих елементів»;

- $\quad$ GB 11887 «Ювелірні вироби. Сплави дорогоцінних металів та позначення».

Зокрема, GB 28480 нормує використання металів у ювелірних виробах у таких кількостях:

- $\quad$ кадмій - не більше 100 мг/кг;

- свинець - для дитячих виробів - не більше 300 мг/кг, для дорослих - 1000 мг/кг;

- $\quad$ нікель - не більше 0,2 мкг $/ \mathrm{cm}^{2} /$ тиждень для предметів пірсингу; не більше 0,5 мкг $/ \mathrm{cm}^{2} /$ тиждень для інших ювелірних прикрас [10].

Варто відмітити, що норми для нікелю та кадмію, які використовуються в Китаї, практично ідентичні європейським та американським, а от вимоги для свинцю значно занижені.

Занепокоєння громадськості та поінформованість про шкідливий вплив кадмію та свинцю на здоров'я людей також сприяли розробці нормативних актів у Бразилії. У листопаді 2013 року Національне агентство охорони здоров'я Бразилії (ANVISA) повідомило, що в порту Ріо-де-Жанейро було затримано партію 16 тонн ювелірних виробів, що містять кадмій. Хоча високі концентрації кадмію, виявлені в цих виробах, не представляли неминучого i значного ризику для громадськості, конфіскація цих товарів призвела до розробки та публікації регламенту в 2016 році 3 метою регулювання використання свинцю та кадмію в ювелірних виробах. Ювелірні вироби, призначені для Бразилії, регулюються Постановою №43 від 22 січня 2016 року, яка обмежує використання кадмію та свинцю в ювелірних виробах та була опублікована 26 січня 2016 року [11].

Висновки та перспективи подальших досліджень. Загалом можна підсумувати, що регулювання використання нікелю або щонайменше зазначення його наявності у маркуванні ювелірного виробу є необхідним для всіх вікових груп через часті алергічні реакції на цей метал. Відсутність кадмію та свинцю є переважно важливим для дітей, оскільки, вони більш схильні поміщати свої прикраси в рот, що сприяє абсорбції металів. Тому рекомендовано забезпечити відсутність кадмію та свинцю у ювелірних виробах для дітей з метою запобігання шкідливих ефектів тривалої експозиції низького рівня кадмію чи свинцю, які можуть проявлятися протягом життя. 
Варто розробити та впровадити державний регламент щодо безпечності ювелірних виробів. Після впровадження необхідних норм та регламентів доцільно провести дослідження їх впливу на здоров'я популяції, щоб довести або спростувати ефективність відповідного законодавства.

\section{Список використаних джерел:}

1. Thyssen J., Menné T. Metal allergy - a review on exposures, penetration, genetics, prevalence, and clinical implications. Available: https://www.ncbi.nlm.nih.gov/pubmed/19831422

2. Fernanda Torres, Maria das Graças, Mota Melo, and Antonella Tosti Management of contact dermatitis due to nickel allergy: an update. Available: https://www.ncbi.nlm.nih.gov/pmc/articles/PMC3047925/

3. M. Nathaniel. Mead CADMIUM CONFUSION: Do Consumers Need Protection? Available: https://www.ncbi.nlm.nih.gov/pmc/articles/PMC3002210/

4. Swedish Chemicals Agency. Dangerous Metals in Jewellery. Available: https://www.kemi.se/global/faktablad/facts-dangerous-metals-in-jewellery.pdf

5. Lead in Jewellery. Available: https://www.dtsc.ca.gov/LeadInJewelry.cfm

6. John F.Rosen Adverse health effects of lead at low exposure levels: trends in the management of childhood lead poisoning. Availale: https://doi.org/10.1016/0300-483X(94)02963-U

7. Bruce P. Lanphear Low-Level Environmental Lead Exposure and Children's Intellectual Function: an International Pooled Analysis. Available: https://www.ncbi.nlm.nih.gov/pmc/articles/PMC1257652/

8. Regulation (EC) No 1907/2006 of the European Parliament and of the Council of 18 December 2006 concerning the Registration, Evaluation, Authorisation and Restriction of Chemicals (REACH), establishing a European Chemicals Agency, amending Directive 1999/45/EC and repealing Council Regulation (EEC) No 793/93 and Commission Regulation (EC) No 1488/94 as well as Council Directive 76/769/EEC and Commission Directives 91/155/EEC, 93/67/EEC, 93/105/EC and 2000/21/EC (Text with EEA relevance). Available: http://data.europa.eu/eli/reg/2006/1907/2014-04-10/

9. Canada Consumer Product Safety Act. Available: https://lawslois.justice.gc.ca/eng/acts/C-1.68/

10. China: mandatory standarts GB 28480 for jewelry comes into force. Available: https://www.sgsgroup.com.hk/en/news/2013/09/china-mandatory-standards-gb-28480-for-jewelry

11. Chemicals in Jewelry: What's Safe for International Markets. Available: https://www.sgs.com/en/news/2016/07/chemicals-in-jewelry-whats-safe-for-international-markets

Цель. Целью данной статьи является анализ влияния никеля, кадмия и свинца на организм человека, а также изучение уже существующего опыта внедрения норм их использования в ювелирных изделиях для разработки практических рекомендаций по разработке регламентов, ограничивающих использование никеля, кадмия и свинща в ювелирных сплавах.

Методика. Использованы методы теоретического поиска, системного подхода и логического обобщения. 
Результаты. Анализ данных свидетельствует, что на украинском рынке 20\% ювелирных сплавов не стандартизированы, и вопрос их качества вызывает сомнения. $B$ частности, не регламентировано использование потенциально вредных элементов. В статье проанализированы данные о влиянии никеля, кадмия и свинца на организм человека. Особое внимание уделено влиянию вредных элементов на детский организм, поскольку детские ювелирные изделия чаще всего изготавливаются именно из сплавов, содержащих кадмий и никель. Для детских изделий возможна потенциальная пероральная миграџия элементов вовнутрь организма. Основной сложностью изучения влияния низких доз на здоровье людей является то, что результаты их проникновения и накопления в организме в детстве могут проявляться в течение всей жизни.

Определены основные нормы регламентов различных государств, регулирующие использование этих металлов в ювелирных изделиях. Проведено их сравнение и анализ, в частности, определено, что нормы по содержанию кадмия и никеля в регламенте Евросоюза REACH, американских стандартах ASTM F2999 и F2923, канадском SOR / 2018-82 и китайском GB 28480 практически идентичны. Однако относительно норм по содержанию свинца существенно различаются: европейские и американские нормы более строгие, почти в 10 раз. Доказана необходимость разработки начионального регламента, который способствовал бы регулированию использования никеля, кадмия и свинца в ювелирных изделиях.

Научная новизна. Проблема регулирования содержания вредных веществ, в частности таких металлов как никель, кадмий и свинеи, в ювелирных изделиях до сих пор не получила должного внимания во многих государствах. В данной статье рассмотрень основные причины внедрения соответствующих регламентов и проанализированы их наличие и эффективность в мире.

Практическая значимость. Разработаны рекомендации, которые должны стать толчком для регулирования содержания никеля, кадмия и свиния в ювелирных сплавах в частности в Украчне.

Ключевые слова: никель, кадмий, свинеи, контактная аллергия, ювелирные изделия, регламент.

Purpose. The use of nickel, cadmium and lead in jewellery has been chosen as the object of this article due to the fact that these metals are the common cause of various disorders in the general population.

Methodology. Methods of theoretical search, system approach and logical generalization are used.

Results. Such metals as nickel, cadmium and lead may influence human health even in low concentrations. Therefore their use in jewellery is considered to be dangerous. Nickel in the alloy can cause allergic contact dermatitis whereas cadmium and lead in children's jewellery can influence the development of different organs and systems. For that reason the use of nickel, cadmium and lead in jewellery should be regulated by the government structures. A number of countries have already successfully implemented the regulations that restrict the use of these metals in jewellery. Hopefully, their experience will help to implement such regulations worldwide in order to provide the safety of consumers by avoiding the use of nickel, cadmium and 
lead in jewellery alloys. The norms for nickel and cadmium, which are used in China are almost identical to European and American, but the requirement for lead is significantly underestimated. Overall, it may be concluded that it is necessary to regulate the use of nickel in jewellery or at least mention its presence in the alloy in the labelling of jewellery for all age groups because of the frequent allergic reactions to this metal. Therefore it is advisable to provide the regulations that prohibit the use of cadmium and lead in children's jewellery in order to prevent the harmful effects of constant low-level exposure of cadmium or lead that can appear throughout a whole human life. After the implementation of all the necessary regulations, it is advisable to carry out a research of their impact on the health of the population in order to prove or disprove the effectiveness of these measures.

Scientific novelty. This article discusses the main reasons for implementing the relevant regulations and analyses their availability and effectiveness in the world.

Practical significance. Recommendations have been developed that should be the impetus for regulating the content of nickel, cadmium and lead in jewellery alloys in particular in Ukraine.

Key words: nickel, cadmium, lead, nickel allergy, children, health effects, standards, regulations.

Стаття рекомендована до друку доктором технічних наук, професором Байдаковою Л.І. Дата надходження в редакиію 05.01.2019 р. 